\title{
C-reactive protein and lipid profile among depot- medroxyprogesterone acetate injections users
}

Wahda B. Al-Youzbaki

Department of Pharmacology, College of Medicine, University of Mosul.

(Ann. Coll. Med. Mosul 2011; 37 (1 \& 2): 48-56). Received: $5^{\text {th }}$ Oct 2010; Accepted: $5^{\text {th }}$ Jun 2011.

\begin{abstract}
Objective: To study the effect of depot-medroxyprogesterone acetate (DMPA) injections on Creactive protein (CRP) and lipid profile and to find the predictors (body weight, body mass index (BMI), blood pressure (BP) and lipid profile) that significantly predict the risk of cardiovascular disease (CVD) among DMPA injections users.

Method: A prospective cohort study was performed during the period from March 2009 to March 2010 included thirty apparently healthy married women, their age ranged between 20-35 years, who were attending Al-Batool and Al-Khansa Family Planning Centers in Mosul and started (for the first time) to use DMPA injections (150 mg medroxyprogesterone acetate), called "Depo-Provera" as contraceptive. These (DMPA users group) were compared to another 30 healthy married women who did not use any hormonal contraceptives (non users group). Both groups were followed for one year, during which blood samples were obtained from both groups, before starting to use DMPA, after 6 months and after 12 months. Sera were used for the estimation of the biochemical studied parameters using commercial kits except serum low density lipoprotein (LDL) and atherogenic index (Al) which were calculated by special equations.

Results: DMPA injections caused a non significant increase in body weight but a significant increase in BMI after 12 months. There was a significant increase in the mean diastolic blood pressure (DBP) of DMPA users according to the duration of use. The DMPA caused non significant changes in the CRP levels. There was a significant increase in serum triglycerides (TG) after 6 months of DMPA uses with respect to the duration of use. But there were non significant changes in mean serum total cholesterol (TC), high density lipoprotein (HDL), LDL and Al. Among all variables that were studied, only body weight and BMI showed a significant positive correlations with CRP. Using a stepwise multiple regression analysis, it was found that the predictors that significantly predict the risk of CVD among DMPA users were AI, DBP and TG.

Conclusion: This study found that there is a significant positive association between CRP and CVD risk factors in DMPA injections users as contraceptive. Furthermore AI, DBP and TG were found to be significant predictors for the risk of CVD among DMPA users. This study confirmed the safety of DMPA use as contraceptive medication, but that special care should be directed for patients with CVD and other patients who were more sensitive to the harmful effects of lipid in the blood.
\end{abstract}

Key words: Depot-medroxyprogesterone acetate, CRP, lipid profile.

الخلاصة

الهاف: لدراسة تأثثر حقن مخزن ميدروكسي بروجيستيرون أسيتيت على البروتين التفاعلي نوع ج ودهون الدم و إيجاد

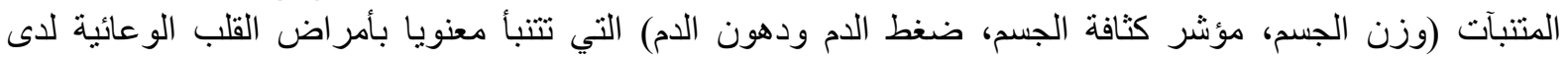
مستعملات مخزن ميدروكسي بروجيستيرون أسيتيت. 


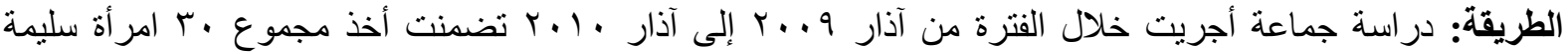

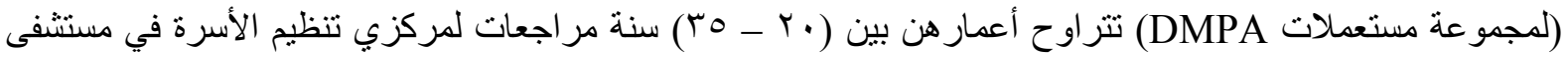

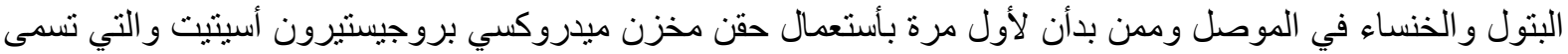
مقارنه" Depo-Provera"

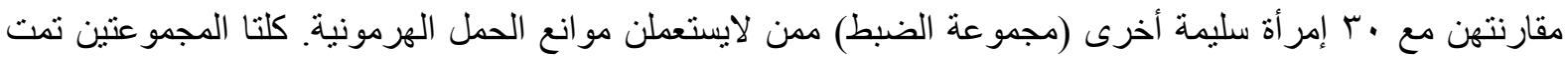

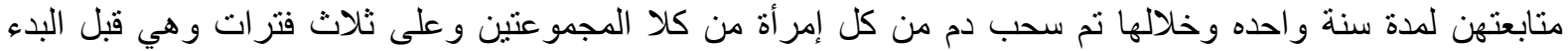

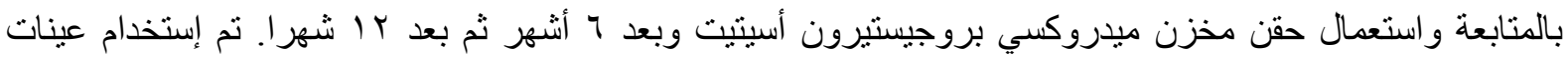
مصل الدم المأخوذة من نماذج الدم لقياس الفحوصات الكيمياوية المدروسة باستعمال العدد اليدوية التجارية ماعدا مؤشر كثافة الجسم، كوليسترول الدهن واطئ الكثافة في مصل الدم ومؤشر التصلب العصيدي باستعمال معادلات خاصة. النتائج: حقن مخزن ميدروكسي بروجيستيرون أسيتيت سبيت زيادة غير معنوية بوزن الجسم ولكن زيادة معنوية بمؤشر

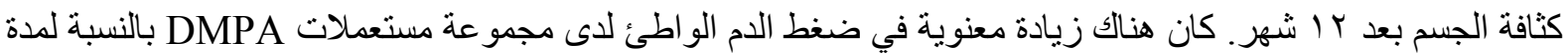

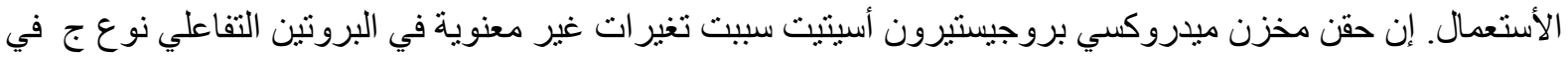

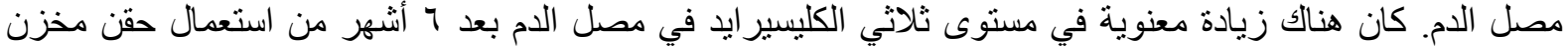

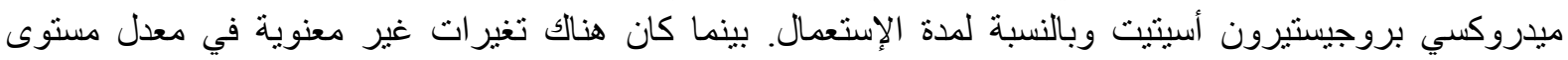

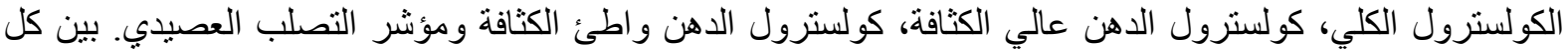

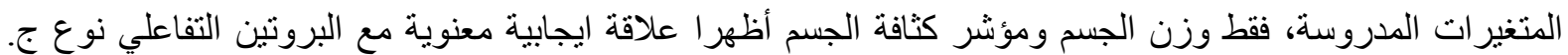

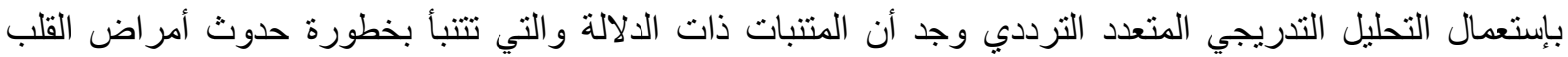
الوعائية لدى مستعملات حقن مخزن ميدروكسي بروجيستيرون كانت: مؤشر التصلب العصبدي، ضغط الدم الواطئ، ثلاثي الكليسير ايد. الاستتتاج: هذه الدراسة وجدت أن هناك مر افقة إيجابية ومعنوية بين البروتين التفاعلي نوع ج و وعو امل الخطورة لأمر اض القلب الوعائية بين مجموعة مستعملات DMPA كمانع للحمل. بالإضافة الى أن مؤشر التصلب العصيدي، ضغنط التئ الدام

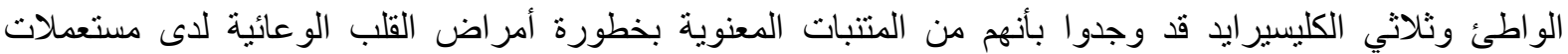
DMPA خاصة يجب أن توجه لمرضى القلب الوعائية وغيرهم من المرضى الذين يكونون أكثر حساسية لتأثثر أضرار الدهون الدهن في

مفتاح الكلمات: مخزن ميدروكسي بروجيستيرون أسيتيت، البروتين التفاعلي نوع ج ودهون الدم.

$\mathrm{D}$ epot-medroxyprogesterone acetate (DMPA) is a highly effective, convenient non-daily hormonal contraceptive option that has been available worldwide for many years. It is approved by the US Food and Drug Administration (FDA) since 1992 and used worldwide by more than 90 million women ${ }^{(1)}$. Long term use of DMPA injections may cause a reduction of menstrual blood loss, decreasing the risk of endometrial cancer and suppression of endogenous estrogen secretion which leads to reversible reduction in bone density and changes in plasma lipids associated with increased risk of atherosclerosis ${ }^{(2)}$.

Since atherosclerosis may in part, be an inflammatory disease ${ }^{(3)}$, circulating factors related to inflammation may be predictors of CVD in general population ${ }^{(4)}$. CRP, a marker of low grade chronic inflammation, has been identified for both men and women as an independent predictor for $C V D^{(5,6)}$ and has recently been shown to provide additional prognostic information to $\mathrm{LDL}^{(7)}, \mathrm{TC}$ and $\mathrm{HDL}$ in women ${ }^{(8)}$. Recent data also indicate that level of CRP adds to the predictive value of lipid parameters in determining risk of a first myocardial infarction ${ }^{(8)}$ and screening based on lipid levels may provide an improved method of identifying women at risk of $C \mathrm{CD}^{(9)}$.

C-reactive protein is not simply a short term marker for risk, as has previously been demonstrated in patients with unstable angina ${ }^{(10)}$, but a long term marker for risk, even 
for events occurring six or more years later ${ }^{(5)}$. The relationship between inflammatory factors and coronary heart disease (CHD) suggests that subclinical chronic inflammation may have a major role in the development of atherosclerosis $^{(11)}$. It is now well established that atherosclerosis originates in early life, and that its risk factors track to adulthood ${ }^{(4)}$.

The relative CVD risk associated with elevated TG levels is greater in women than in $\mathrm{men}^{(12)}$ and the threshold for increased risk from low HDL is higher ${ }^{(13)}$. HDL is atheroprotective as evidenced by a strong inverse association between HDL levels and coronary heart disease $(\mathrm{CHD})$ risk $^{(12)}$. Beside that, HDL levels greater than $60 \mathrm{mg} / \mathrm{dl}(1.55$ $\mathrm{mmol} / \mathrm{l}$ ) which are more commonly found in women than in men, are so protective as to essentially negate the effect of one of other CHD risk factors ${ }^{(14)}$.

Inflammatory processes, along with plasma lipids and lifestyle behaviors, play a pivotal role in the pathogenesis of cardiovascular diseases $^{(7,15)}$. In both men and women, several epidemiological studies now indicate that the relationship between the inflammatory biomarker of high-sensitivity C-reactive protein (hsCRP) and future vascular events is strongly independent of other risk factors and the association of hsCRP with vascular events provided a strong argument for screening in the primary prevention population ${ }^{(7)}$.

The relationship between CRP and the risk of CHD has been shown in adults ${ }^{(4)}$. Despite its widespread use, the cardiovascular effects of DMPA in young women are unclear, so the current study was conducted to investigate the association of serum CRP with body weight, BMI, BP and lipid profile among young DMPA injections users as contraceptives and to find the significant predictors of the risk of CVD among these users.

\section{Subjects and methods}

The approval of the study protocol by an ethical committee was obtained from local health committee of Ministry of Health, and College of Medicine, University of Mosul. This study included 30 apparently healthy married, not pregnant, not lactating women, were fertile at the time of study, having regular menstrual cycle, who were attending Al-Batool and AlKhansa Family Planning Centers in Mosul. A written consents were taken from the women after explanation.

The following inclusion criteria were put: age 20-35 year, BMI < 25, hemoglobin not less than $10.5 \mathrm{~g} / \mathrm{dl}$, and no hormonal contraceptives before, or any medications during the period of the study. No history of allergy or any disease that interferes with the immune system, non smokers, and not alcoholics. They were just started to receive (for the first time) $150 \mathrm{mg}$ DMPA injection (called "Depo-Provera" of Pharmacia NVISA Puurs-Belgium) every 3 months. These women were called DMPA users group. The non users group included another 30 apparently healthy volunteer women who have the same inclusion criteria as the DMPA users group except that they were not using any hormonal contraceptives, instead, they used either a barrier method or mechanical methods. Anthropometric measures (blood pressure $(\mathrm{mmHg})$, body weight $(\mathrm{Kg})$ and height $(\mathrm{cm}))$ were taken. Ten $\mathrm{ml}$ venous blood were withdrawn into plain tube, using a disposable syringe at about 8.30-10.00 am (after 12 hours fasting) from the DMPA injections users group at the beginning before they start taking the injection, after 6 months, then after 12 months of use, and from the non contraceptive users group using the same schedule. The blood was allowed to clot, then serum was separated by centrifugation at $3000 \mathrm{rpm}$ for 10 minutes and then kept frozen at $-20^{\circ} \mathrm{C}$ to be analyzed:

1- Serum CRP was measured by slide agglutination using Biokit, Spain.

2- Measurement of serum TC and TG concentration was done by the enzymatic colorimetric method, using (BioMerieux kits, France) for each.

3- Serum HDL was measured by the precipitation method, using HDL Cholesterol/ Phospholipids kit (BioMerieux, France).

4- Serum LDL was calculated by using Friedewald equation ${ }^{(16)}$ :

LDL $(\mathrm{mmol} / \mathrm{l})=\mathrm{TC}-\mathrm{HDL}-(\mathrm{TG} / 2.19)$

5- Atherogenic index (Al) was calculated by the following equation: $\mathrm{Al}=\mathrm{TC} / \mathrm{HDL}^{(17)}$. 
Standard statistical methods were used to determine the mean, standard deviation (SD) and the range. Paired t-test was used to compare the results of various biochemical parameters among the two groups. Linear regression analysis (Pearson correlation coefficient $($ ) ) was performed for finding the degree of association between different parameters. ANOVA test (analysis of variance) was used to identify the variation in the different variables in relation to the duration of DMPA users group. Duncan's test was used to identify groups responsible for statistical difference through comparison. Linear Stepwise Multiple Regression Technique was applied to detect the significant independent (predictors) variables that predict CVD risk among DMPA users. All values quoted as the mean \pm SD and a P-value of $\leq 0.05$ was considered to be statistically significant.

\section{Results}

The obligatory use of DMPA injections every 3 months led the users women to visit the Family Planning Center regularly and eventually every 3 months to take the injection, so all women enrolled in this study can be followed up with less possibility of loss to follow up.

There was no significant difference between mean \pm SD of age of the DMPA users (28.36 \pm 4.14 years $)$ and of the non users $(27.40 \pm 4.71$ years). There was no significant difference between mean \pm SD height of the DMPA users $(157.57 \pm 3.33 \mathrm{~cm}$.), and that of the non users $(159.30 \pm 3.25 \mathrm{~cm}$.).

This study indicates that DMPA caused a non significant increase in body weight among DMPA users in comparison with non users after 6 and 12 months. Although DMPA use caused an increase in BMI of the DMPA users in comparison with non users after 6 and 12 months, only the increase after 12 months was significant. However ANOVA analysis of the DMPA users group revealed a non significant $(F=1.67, p=0.207)$ increase in the mean BMI of the DMPA users in relation to the duration of usage (table 1).
Table (1): Comparison between mean BMI of DMPA users and non users.

\begin{tabular}{|c|c|c|c|}
\hline \multirow{2}{*}{$\begin{array}{c}\text { Period } \\
\text { of use } \\
\text { (Months) }\end{array}$} & \multicolumn{2}{|c|}{$($ Mean $\pm \mathrm{SD}) \quad \mathrm{BMI}\left(\mathrm{kg} / \mathrm{m}^{2}\right)$} & \multirow[b]{2}{*}{ P-value } \\
\hline & $\begin{array}{l}\text { DMPA Users } \\
\qquad(n=30)\end{array}$ & $\begin{array}{c}\text { Non Users } \\
(n=30)\end{array}$ & \\
\hline 0 & $\begin{array}{c}22.186 \pm \\
1.986 \mathrm{a}\end{array}$ & $\begin{array}{c}22.25 \pm \\
1.94\end{array}$ & 0.946 \\
\hline 6 & $\begin{array}{c}23.24 \pm \\
2.54 \mathrm{a}\end{array}$ & $\begin{array}{c}21.95 \pm \\
2.11\end{array}$ & 0.255 \\
\hline 12 & $\begin{array}{c}24.36 \pm \\
3.28 a\end{array}$ & $\begin{array}{c}21.83 \pm \\
2.33\end{array}$ & 0.042 \\
\hline
\end{tabular}

- (a, b) different letters (vertically), means significant difference.

This study demonstrated that the use of DMPA injection causes a non significant increase in SBP and DBP among DMPA users in comparison with the non users after 6 and 12 months. ANOVA analysis among the DMPA users group indicated a non significant increase in the mean SBP of the DMPA users from non users, but a significant $(F=3.41$, $p=0.048$ ) increase in the mean DBP of DMPA users according to the duration of DMPA injections use.

There were no significant changes in the mean serum CRP among DMPA users in comparison to the non users after 6 and 12 months. ANOVA analysis of the DMPA users indicated that there were non significant changes in serum CRP among DMPA users in relation to the duration of DMPA injections usage.

Table (2) demonstrates that there was a significant increase in serum TG after 6 months in the DMPA users in comparison with the non users. There was no significant difference in the mean serum TG of the DMPA users and non users at the baseline time ( 0 month). ANOVA analysis among the DMPA users group indicated a significant $(F=5.27$, $p=0.012)$ increase in the mean serum TG according to the duration of DMPA injections use. 
Table (2): Comparison between mean serum TG of DMPA users and non users after $6 \& 12$ months.

\begin{tabular}{|c|c|c|c|}
\hline \multirow{2}{*}{$\begin{array}{c}\text { Period of } \\
\text { use } \\
\text { (Months) }\end{array}$} & \multicolumn{2}{|c|}{$\begin{array}{c}\text { (Mean } \pm \text { SD) Serum TG } \\
(\mathrm{mmol} / \mathrm{l})\end{array}$} & \multirow[b]{2}{*}{$\mathrm{P}$-value } \\
\hline & $\begin{array}{l}\text { DMPA } \\
\text { Users } \\
(n=30)\end{array}$ & $\begin{array}{l}\text { Non Users } \\
\quad(n=30)\end{array}$ & \\
\hline 0 & $\begin{array}{c}0.97 \pm \\
0.402 \mathrm{a}\end{array}$ & $\begin{array}{c}1.324 \pm \\
0.732\end{array}$ & 0.430 \\
\hline 6 & $\begin{array}{l}1.82 \pm \\
0.79 \mathrm{a}\end{array}$ & $\begin{array}{l}1.025 \pm \\
0.57\end{array}$ & 0.017 \\
\hline 12 & $\begin{array}{l}1.913 \pm \\
0.66 \mathrm{~b}\end{array}$ & $\begin{array}{c}1.66 \pm \\
0.84\end{array}$ & 0.226 \\
\hline
\end{tabular}

- (a, b) different letters (vertically), means significant difference.

There were non significant changes in the mean serum TC, HDL, LDL, and Al among DMPA users in comparison to the non users after 6 and 12 months. ANOVA analysis of the DMPA users group indicated that there were non significant changes in serum TC, HDL, LDL and Al among DMPA users in relation to the duration of DMPA injections usage.

This study demonstrated that among all variables that were studied, only body weight and $\mathrm{BMI}$ showed a significant positive correlations with CRP $(r=0.733, P=0.016 ; r=$ $0.612, P=0.057$ respectively). By using linear stepwise multiple regression to account for any co depended effects of different biochemical parameters (using CRP) and other biochemical parameters (variables), the predictors that increase the risk of CVD significantly among DMPA users are AI, DBP and TG serum levels. (table 3).

Table (3): Linear multiple stepwise regression model for predictor of CVD in the DMPA users after 12 months.

\begin{tabular}{|c|c|c|c|}
\hline $\begin{array}{c}\text { Variable Xi } \\
\text { (Predictors) }\end{array}$ & $\begin{array}{c}\text { Regression } \\
\text { Coefficient }\end{array}$ & $\begin{array}{c}\text { Standard } \\
\text { Error (SE) }\end{array}$ & $\begin{array}{c}\text { P- } \\
\text { value }\end{array}$ \\
\hline Al & -2.700 & 0.394 & 0.021 \\
\hline DBP & -0.312 & 0.053 & 0.028 \\
\hline TG & -2.000 & 0.677 & 0.038 \\
\hline
\end{tabular}

\section{Discussion}

This study found that there is a significant positive association between CRP and CVD risk markers in DMPA injections users as contraceptive, also CRP can be used as independent risk factor to predict other risk factors by using linear stepwise multiple regression to account for any co depended effects of different biochemical parameters (variables). It is found that the predictors that increase significantly the risk of CVD among DMPA users are Al, DBP and TG serum levels. To the best of our knowledge no previous study done to investigate such theory in DMPA injections users as contraceptive.

This study found that DMPA caused a non significant increase in body weight among the DMPA users in comparison with the non users after 6 and 12 months but caused a significant increase in BMI after 12 months in comparison to non users. This is not of clinical importance since comparison of changes with their respective pretreatment values were not statistically significant. This is in agreement with some studies ${ }^{(15,18)}$, while other studies found that prolonged use of DMPA for 1-2 years in Navajo women ${ }^{(19)}$ and for 3-5 years ${ }^{(20)}$ caused a significant increase in body weight.

This study demonstrated that among all variables that were studied, only body weight and BMI showed significant positive correlations with CRP, but neither body weight nor BMI were significant predictor for the risk of CVD among DMPA users. Studies performed among different ethnic groups showed diverse results, but all these studies confirmed a relationship between serum CRP and both generalized and abdominal obesity $^{(21)}$.

Among men and women with CHD, CRP was correlated with traditional risk factors and to a lesser degree to manifestation of $\mathrm{CHD}$ and $\mathrm{BMI}$ is the main contributor to CRP variability, explained by these factors among women ${ }^{(22)}$. Another study found a significant positive association between CRP and atherosclerotic risk factors in healthy young people, as well as an increase in these markers in the upper quartiles of waist circumference, but not BMI (23). 
In this study there was a non significant increase in SBP and DBP among DMPA users in comparison with the non users after 6 and 12 months. Non significant increase in the mean (SBP) but a significant increase in the mean (DBP) of DMPA users in comparison of changes with their respective pretreatment values was found. The study of Mia et al., ${ }^{(20)}$ found that long term use of DMPA caused insignificant increase in SBP and DBP, but a significant increase in body weight, while the study of Al-Banna ${ }^{(24)}$ found that the use of hormonal contraception cause a non significant changes in body weight, SBP and DBP.

This study revealed that DBP is one of the significant predictors for the risk of CVD among DMPA users by using CRP as the co depended variable. Hashimoto et al.., ${ }^{(25)}$ found that in hypertensive patients being managed by drug therapy or lifestyle modification, CRP is an equivalent or superior independent predictor of the progression of carotid atherosclerosis than the pulse pressure or systolic blood pressure.

This study found that there were non significant changes in mean serum CRP level among DMPA users in comparison to the non users after 6 and 12 months and in relation to the duration of use. This is in agreement with the study of Goldstein et al., ${ }^{(26)}$ who found that the CRP was not significantly altered by the use of DMPA for 12 months.

This study also revealed that the use of DMPA injections as contraceptive in young women caused a significant increase in serum TG after 6 months in the DMPA users in comparison with the non users and according to the duration of use. However there were non significant changes in mean serum TC, HDL, LDL and Al among DMPA users in comparison to the non users after 6 and 12 months nor in relation to the duration of use. This is in agreement with the study of GarzaFlores et al., ${ }^{(27)}$ who found that the use of DMPA for 5 years causes a moderate increase in the serum TG, but a moderate non significant decrease in $\mathrm{TC}$ and $\mathrm{HDL}$, with unchanged LDL. Fahmy et al., ${ }^{(28)}$ found that after 3 months use of DMPA, there were no significant changes in TC and TG, while there was a significant decrease in $\mathrm{HDL}$, and a significant increase in LDL. After 15 months there was a significant increase in TC and LDL and a significant decrease in HDL. The study of Faddah et al., ${ }^{(29)}$ although demonstrated that neither mean serum TC nor TG were affected by DMPA use, only Al was gradually but non significantly increased in comparison to control group as in this study.

Controversial results from different studies were found of the metabolic effects of long term DMPA use. Some studies found that there are non significant changes in lipid profile parameters ${ }^{(29,30,31)}$ including $\mathrm{Al}^{(32)}$ after one year use of DMPA, and concluded that DMPA may be considered as a safe contraceptive medication as the overall data indicate that acute and/or chronic DMPA use at the dose currently employed for contraception does not induce major abnormalities in serum lipoproteins. While other studies found that long term use of DMPA injections as contraception causes significant increase in the mean serum TC, TG and LDL levels, but a non significant decrease in HDL in comparison to that of the control group $^{(33)}$. Other studies found that DMPA use for 12 weeks $^{(34)}$ or for one year ${ }^{(35)}$ caused significant decrease in HDL level, and suggested that DMPA should not be prescribed to women with abnormally high risk for atherosclerosis such as heavy smokers and women with adiposity and /or diabetes mellitus.

This study found that one of the predictors that significantly predicts the risk of CVD among DMPA users were Al and TG. Despite extensive research, it has not yet been determined whether TG represent an independent risk factor for CHD. The association has been obscured by imprecision in TG measurements, individual variability, and complex interactions between TG and other lipid-nonlipid parameters. Although current guidelines do not mandate screening for elevated TG levels in the general population, obtaining TG levels in those with known CHD or with other risk factors can provide valuable prognostic information and therefore be of aid 
in therapeutic decisions ${ }^{(36)}$. Models incorporating both hs-CRP and lipid parameters have significantly greater ability to model using lipid alone ${ }^{(37)}$.

\section{Conclusion}

In the present study, the predictors that predict significantly the risk of CVD (represented by CRP) among DMPA users were AI, DBP and TG serum levels. This means that incorporating both CRP level, lipid parameters and blood pressure have a significantly greater ability to predict CVD risk among DMPA users than model using lipid profile alone.

\section{References}

1. Bakry S, Merhi ZO, Scalise TJ, Mahmoud MS, Fadiel A, Naftolin F. Depotmedroxyprogesterone acetate: an update. Arch Gynecol Obstet 2008; 278(1):1-12.

2. Greenberg GM, Apgar BS (2003). Family planning and contraception. In: family Medicine. Principles and Practice. 6th ed. Taylor RB, Dard AK, Fields SA, Philips $D M$, Scherger $J E$, editors. SpringerVerlag. USA. PP 859-866.

3. Ross R. Atherosclerosis-an inflammatory disease. N Eng J Med 1999;340:115-126.

4. Danesh J, Wheeler JG, Hirschfield GM, Eda S, Eiriksdottir G, Rumley A et al. Creactive protein and other circulating markers of inflammation in the prediction of coronary heart disease. $\mathrm{N}$ Engl $\mathrm{J}$ Med 2004;350(14):1387-1397.

5. Ridker PM, Cushman M, Stampfer MJ, Tracy RP, Hennekens $\mathrm{CH}$. Inflammation, Aspirin, and the risk of cardiovascular disease in apparently healthy men. $\mathrm{N}$ Eng J Med 1997; 336(14): 973-979.

6. Ridker PM, Buring JE, Shil J, Matias M, Hennekens $\mathrm{CH}$. Prospective study Creactive protein and the risk of future cardiovascular events among apparently healthy women Circulation 1998; 98: 731733.

7. Ridker PM, Rifai N, Rose L, Buring JE, Cook NR. Comparison of C-reactive protein and low density lipoprotein cholesterol levels in the prediction of first cardiovascular events. $\mathrm{N}$ Engl J Med 2002; 347: 1557-1565.
8. Ridker PM, Glynn RJ, Hennekens CH. Creactive protein adds to the predictive value of total and HDL cholesterol in determining risk of first myocardial infarction, Circulation 1998; 97: 20072011.

9. Ridker PM, Hennekens $\mathrm{CH}$, Buring JE, Rifai N. C-reactive protein and other marker of inflammation in the prediction of cardiovascular disease in women. $\mathrm{N}$ Engl J Med 2000; 342 (12): 836-843.

10. Haverkate F, Thompson SG, Pyke SDM, Gallimore JR, Pepys MB. Production of Creactive protein and risk of coronary events in stable and unstable angina. Lancet 1997; 349: 462-466.

11. Ridker PM, Buring JE, Cook NR, Rifai N. C-reactive protein, the metabolic syndrome, and risk of incident cardiovascular events: an 8-year follow-up of 14719 initially healthy American women. Circulation 2003;107:391-397.

12. Castelli WP. Cardiovascular disease in women. Am J Obstet Gynaecol 1988; 158 : 1553-1560.

13. 13-Castelli WP, Anderson K. A population at risk: Prevalence of high cholesterol levels in hypertensive patient in the Framingham study. Am J Med 1986; 80: 23-32.

14. Grundy SM. Guidelines for cholesterol management: recommendations of the National Cholesterol Education Program's adult treatment. Panel II. Heart Dis Stroke 1994; 3(3):123-127.

15. Lee KW, Lip GY. Effects of lifestyle on hemostasis, fibrinolysis, and platelet reactivity: a systematic review. Arch Intern Med 2003;163:2368-2392.

16. Friedewald WT, Levy RJ, Fredrickson DS. Estimation of the concentration of LDL-C in plasma without use of the preparative ultracentrifuge. Clin Chem 1972; 18: 499502.

17. Guven A, Ozgen T, Aliyazicioglu Y. Adiponectin and resisten concentrations after load in adolescents with polycystic ovary syndrome. Gynecol Endocrinol 2010; 26(1): 30-38. 
18. Moore LL, Valuck R, McDougall C, Fink W. A comparative study of one-year weight gain among users of medroxyprogesterone acetate, levonorgestrel implants, and oral contraceptives. Contraception 1995; 52(4): 215-219.

19. Espey E, Steinhart J, Ogburn T, Qualls C. Depo-provera associated with weight gain in Navajo women. Contraception 2000; 62(2):55-58.

20. Mia AR, Siddiqui NI, Khan MR, Shampa SS, Rukunuzzaman, Akhter $M$, et al. Effect of prolonged use of injectable hormonal contraceptives on blood pressure and body weight. Mymensingh Med J 2004;13(1):30-32.

21. Barbeu $P$, Litaker MS, Woods KF, Lemmon CR, Humphries MC, Owen S, et al. Haemostatic and inflammatory markers in obese youths: effects of exercise and adiposity. J Pediatr 2002;141:415-420.

22. Benderly M, Haim M, Boyko V, Tanne D, Behar S, Matas Z, et al. C-reactive protein distribution and correlates among men and women with chronic coronary heart disease. Cardiol 2007;107(4):345-353.

23. Kelishadi R, Sharifi M, Khosravi A, Adeli K. Relationship Between C-Reactive Protein and Atherosclerotic Risk Factors and Oxidative Stress Markers Among Young Persons 10-18 Years Old. Clin Chem 2007;53:456-464.

24. Al-Banna IMJ (2004). Effects of contraceptives on body weight, blood pressure, serum glucose, liver enzymes and lipid profile, MSc Thesis in Pharmacology, College of Medicine, University of Mosul.

25. Hashimoto $H$, Kitagawa $K$, Hougaku $H$, Etani H, Hori M. Relationship between CReactive protein and progression of early carotid atherosclerosis in hypertensive subjects. Stroke 2004;35:1625-1630

26. Goldstein J, Cushman M, Badger GJ, Johnson JV. Effect of depomedroxyprogesterone acetate on coagulation parameter: a pilot study. Fertil Steril 2007;87(6):1267-1270.
27. Garza-Flores J, De la Cruz DL, Valles de Bourges V, Sanchez-Nuncio R, Martinez $M$, Fuziwara JL, et al. Long-term effects of depot-medroxyprogesterone acetate on lipoprotein metabolism. Contraception 1991;44(1):61-71

28. Fahmy K, Khairy M, Allam G, Gobran F, Alloush M. Effect of depomedroxyprogesterone acetate on coagulation factors and serum lipids in Egyptian women. Contraception 1991; 44(4):431-444.

29. Faddah LM, Al-Rehany MA, Abdel-Hamid NM, Bakeet AA. Oxidative stress, lipid profile and liver functions in average Egyptian long term depo medroxy progesterone acetate (DMPA) users. Molecules 2005;10(9):1145-1152.

30. Mainwaring R, Hales HA, Stevenson K, Hatasaka $\mathrm{HH}$, Poulson AM, Jones KP, et al. Metabolic parameters, bleeding, and weight changes in U.S. women using progestin only contraceptives. Contraception 1995;51(3):149-153.

31. Amatayakul K, Sivassomboon B, Singkamani R. Effects of medroxyprogesterone acetate on serum lipids, protein, glucose tolerance and liver function in Thai women. Contraception 1980; 21(3):283-297.

32. Anwar M, Soejono SK, Maruo T, Abdullah $\mathrm{N}$. Comparative assessment of the effects of subdermal levonorgestrel implant system and long acting progestogen injection method on lipid metabolism. Asia Oceania J Obstet Gynaecol 1994; 20(1): 53-58.

33. Mia AR, Siddiqui NI, Islam MN, Khan MR, Shampa SS, Rukunuzzaman M. Effects of prolonged use of injectable hormonal contraceptive on serum lipid profile. Mymensingh Med J 2005; 14(1):19-21.

34. Kremer J, de Bruijn HW, Hindriks FR. Serum high density lipoprotein cholesterol levels in women using a contraceptive injection of depot-medroxyprogesterone acetate. Contraception 1980; 22(4):359367.

35. Kremer J, de Bruijn HW, Hindriks FR. [Injectable contraceptive, DMPA, serum 
HDL cholesterol and heart infarct]. Ned Tijdschr Geneeskd 1981;125(35):14181421.

36. Gaziano JM. Triglycerides and coronary risk. Curr Cardiol Rep 1999;1(2):125-130.
37. Kluft C. Identifying patients at risk of coronary vascular disease: the potential role of inflammatory markers. Eurp Heart $\mathrm{J}$ 2004; 6 (Suppl C): 21-27. 